\title{
Democracy by accident: the rise of Zuma and the renaissance of the tripartite alliance
}

\section{Laurence Piper and Heidi Matisonn}

In party organisational terms, the rise of Jacob Zuma to the Presidency of the African National Congress (ANC) is a victory for the alliance partners and the struggle-era vision of the ANC as a popular front, or the 'ANC as alliance', as against Mbeki's centralised and exclusionary practice. Accidentally, this renaissance of the ANC as alliance is good for democracy in South Africa understood in both liberal and participatory terms. On the one hand, the factionalism in the party provided for an alternation of leadership not possible through formal elections; and perhaps not desirable at this time. Further, the emergence of Congress of the People (COPE) promises a more meaningful party pluralism, taking the pressure for democratic competition off ANC internal processes into the future. On the other hand, the renaissance of the ANC as alliance provides better access to government by organisations, especially COSATU, who have a proven record in mobilising working and poor people around key social issues from land to HIV-AIDS and Zimbabwe. In this way the chances of greater inclusion in national decision-making are heightened, at least for some marginalised groups.

\section{Introduction}

This article explores the significance of the recent conflict within the African National Congress (ANC) for democracy in South Africa. More specifically we interrogate the deeper meaning of the succession struggle between Thabo Mbeki and Jacob Zuma, as well as the hiving off of a disenchanted group of leadership to a new party, the Congress of the People (COPE). In brief our argument is that for those who hold that the meaning of democracy is primarily exhausted by multi-party electoral competition, the recent succession struggle gives reason for optimism about democratic consolidation in South Africa.

This is because the competition in the ANC's internal processes is closely analogous to a competition in formal electoral processes. Not only was there open competition for the vote in which the most popular candidate won, but this competition was between leadership rooted in constituencies that broadly reflect the major interests groups in the country. Further, this intra-party competition followed and affirmed democratic rules, at least in the electoral phase of ANC processes, and thus allowed for elite alternation without threatening the status of the ANC as the leading party, a threat the country might not be ready to tolerate. Indeed, given the recent transition to democracy in South Africa some fifteen years ago, the rise of Zuma represents a form of elite alternation most optimal to consolidation, by bringing the benefits of elite competition without the risks of party alternation and with it a potential threat to the new system as a whole.

Of course it might be countered that the leadership struggle in the ANC has brought populist or patrimonial rather than sober and wise leadership. Indeed, it might also be true that the new elite are no more supportive of key democratic values than the old guard, and perhaps even less supportive. However these kinds of good governance outcomes are not guaranteed by any generation Schumpeterian model. The focus of mainstream consolidation theory is overwhelmingly on democracy as competition for popular support, not democracy as good government, nor even democracy as rooted in values of liberty, equality and fraternity.

Hence, more threatening to the mainstream view are potential disanalogies between the competition within the ANC and electoral competition. More specifically it could be argued that the various ANC factions did not operate as political parties in the sense that they did not observe certain basic conditions of electoral competition such as transparent platforms and the non-coercion of voters. ${ }^{1}$ However the available evidence suggests that these objections are far from fatal. Simply put, the competition in the ANC was both public, and free and fair enough, to truly reflect opinion in the party, and probably in the country at large. The forthcoming election will truly redeem this claim, but it is notable that all commentators expect the ANC to win comfortably in 2009.

In making the case that the ANC succession race has done something like the job that elections are meant to do, indeed a better job by not threatening fundamentally the ANC and thus the new democratic order, our argument also exposes some typical limitations of consolidation theory, indeed all versions of associational or plural democracy. Already it is conceded that elite alternation through elections is no guarantee of leaders who are good people, nor of leaders who are, in any sense, good politicians. Sometimes leaders just get lucky. Nor is it any guarantee of selecting leaders who embrace democratic values. All it really guarantees is a system which protects the option to get rid of unpopular leaders when someone who is preferred comes along.

Further, even the more nuanced versions of associative democracy allow little space for substantial citizenship beyond voting, lobbying and public debate, offering mechanisms of elite accountability that lack both real precision and purchase. The only mechanism with purchase, voting, lacks precision, as the choice is always a package deal of mixed preferences, and the mechanisms which offer more precision, such as public debate, have no real purchase on elite decision-making. This reality connects with broader debates about the 
'democratic deficit' of liberal-democratic capitalism in both the developed and developing world, and an emergent wave of political experimentation that looks to deepen the meaning of democracy as loosely responsive elite rule.

Welcome to the Post-Colony: Change, Concern and Uncertainty in South Africa Politics

Addressing the AGM of the Law Society of South Africa on 31 March 2008, Professor Barney Pityana (2008), Principal of the University of South Africa, stated:

We now enter a new era. It is a time shrouded in anxiety and uncertainty with the looming Presidency of Jacob Zuma and a new assertive leadership of the ANC. To many of us, Jacob Zuma, popularly elected by the branch delegates at Polokwane in December 2007, remains a flawed character in his moral conduct. He has been indicted for serious crimes that involve corruption and dishonesty. So far, he does not encourage confidence in his understanding of policy, appearing as he does in the short-term to be making policy pronouncements on- the-hoof depending on who he wishes to appease at any one moment.

We have seen the leader flip-flop on crucial matters of policy, for example, the death penalty; the silence when his supporters mount a savage and uninformed attack on the judges ostensibly with his concurrence; the dance of back step on the reform of the labour market, and so on. The new ANC seems much more at ease settling scores, scrambling for positions or positioning themselves, than it does addressing the problems that confront this country: poverty, unemployment, social cohesion, crime, skills and technology.

For his comments, and for these words in particular, Professor Pityana, came in for some substantial criticism. The ANC secretary-general Gwede Mantashe described Pityana's statements as 'spurious' and a reflection of 'intellectual bankruptcy'. Mantashe said Pityana's statements were an indication that Pityana was clinging to personalities and failing to view the organisation, the ANC, as a whole. Pityana also did not understand Zuma, Mantashe said (SAPA 1 April 2008). Outgoing African National Congress Youth League (ANCYL) president Fikile Mbalula said 'Yet again Professor Pityana has made a clown of himself by his overzeal- ous confusion and comical postulations about the ANC president and the ANC leadership'. Mbalula accused Pityana of being a typical ivory-tower academic and ignorant reactionary who had to sober up and cross over the road from Polokwane. 'The train has long passed the station and it's time he (Pityana) wakes up from the slumberland and smells the coffee' (Mail \& Guardian 3 April 2008).

This interchange captures neatly themes of change, concern and uncertainty that hang over South African politics. First is change. A long and public political struggle has seen Jacob Zuma supplant Thabo Mbeki as the President of the ANC. Perhaps just as significantly, the composition of the ANC NEC has changed to reflect the ascendancy of Zuma supporters. In subsequent months those associated with the Mbeki camp have been systematically marginalised, and some of those disgruntled with the new leadership, principally former Minister of Defence Mosiuoa Lekota, and former Premier of Gauteng, Mbhazima Shilowa, have left the ANC to form a new party, COPE.

Speculation in the media has put the possible electoral support for COPE at no more than 20\%, and more recently at less that $10 \%$, but nevertheless support which would leave the ANC with a much reduced majority (Mail\& Guardian 18 November 2008). If these guesti- mates are accurate, and assuming that these voters are won away from the ANC, it would signal the beginning of an opposition party with real potential to challenge ANC dominance in time given its liberation credentials and experienced leadership. While this change in itself is dramatic, the shift is rendered all the more controversial and uncertain given the corruption court-case brought against Zuma which, despite recent rulings in Zuma's favour, remain unresolved with a national election looming.

Changes in the South African political landscape have been matched by concern over the future of the country. Much of this has to do with the character of Zuma as a leader-as intimated above by Pityana. Over the last few years Zuma has been portrayed in the public realm as a corrupt politician, directly involved in receiving money from the French arms manufacturer, Thint Holdings. Indeed, his financial adviser, Shabir Shaik, was convicted on corruption and fraud charges in 2007 for payments he and his companies made to Zuma.

Zuma has also been portrayed as a misogynist, both for being a traditionalist Zulu patriarch (as evidenced by his polygamy), and by charges of rape that were brought against him in 2006 by a 31-year-old family friend with whom he admitted to having sex. He further endured much ridicule and criticism for having unprotected sex with this woman, whom he knew was HIV positive, and then 'taking a shower' to reduce the risk of infection. Further, he did all this despite being head of the South African National Aids Council (SANAC). Because of his lack of formal education beyond grade six, and his clear unpreparedness for interviews with foreign media he has also been cast as ignorant of modern ways, and a political populist who will say whatever he thinks his audience wants to hear.

In sum, Zuma has been represented as embodying many of the pathologies of the neo-patrimonial, 'big-man', politics that has plagued post-independence Africa. Based around personalities and patronage networks, this kind of politics has been found to be anti-thetical to the rule of law, clean, transparent and efficient government, sustained economic growth, a democratic political culture and women's rights. Related concerns 
focus on the future direction and quality of governance under a Zuma Presidency. Although backed heavily by the left, specifically COSATU and the South African Community Party (SACP), it is far from clear that Zuma is indeed genuinely committed to any more left-leaning politics than Mbeki. Add to this the characters of dubious reputation associated with the Zuma camp, and uncertainty looms.

At one level the change, concern and uncertainty that has characterised recent South African politics appear to centre on the personalities and attributes of two men who are presented in the public realm as a study in contrasts. Mbeki is portrayed as the visionary, intellectual, philosopher-King behind the African renaissance; an urbane and savvy Africanist capitalist, aloof in style and remote in experience from most 'ordinary' citizens. Zuma, by contrast, is portrayed as 'of the people'. From a poor rural area, with limited education, and sharing many popular values, Zuma is the new South African dream-an ordinary boy who made good despite his disadvantaged background. His popularity is also rooted in a public persona constructed as a sometimes slightly gormless, but warm and accessible human being in personality and political belief. This series of binary contrasts encapsulates in microcosm the tensions and contradictions of post-colonial politics. This in itself is fascinating, especially as all believe that some aspect of this characterisation is untrue.

Both the presentation of these mutually exclusive post-colonial archetypes and their dubious relationship with reality demand further inquiry, but this is not the task of this article. Rather, it is to look beyond South African politics as about a clash of 'imagined personalities' to identify deeper processes of change, and to begin to try and make sense of those. Indeed, what is so fascinating about the above Pityana exchange is the way that the entire sum of South African political life is encapsulated in the battle for leadership of the ANC. What has gone before is all Mbeki, and what is to come is all Zuma. It is like the great man theory of history reinvented South African style.

But is South African politics really reducible to the Presidency? More specifically are we a democracy only by dint of the ANC leader? Can Zuma undo South Africa like Robert Mugabe (apparently) has undone Zimbabwe? If so, is this always the ways things are, or is it a contingent outcome of Mbeki's centralisation of power, and other historically-specific processes? If South African political life is more than just the President, how much more is it? Is it the ANC? Is it party competition? Is it the economy? Is it our political values? Is it some combination of the above?

One of our tasks here is to draw attention away from analysing politics as personality, and to think more about politics as practice, and in particular, the relationship between political practice and political institutions, movements and culture. So this article will not compare and contrast Mbeki and Zuma as Presidents (real and potential). One of the arguments of this article is that the ANC under Zuma is much more likely to be a politics less centred on one personality, not because Zuma is morally superior to Mbeki, but because the balance of power has changed between the political movements that constitute the ANC. In this regard it is important to note the subsequent comment Pityana (2008) made in his speech-a comment which, notably, has gone unreported:

And yet, it must be stated, the new ANC as a political party perhaps holds the promise of a new era in politics. Perhaps the ANC may present itself as a party of reform: a more popular and participatory party that respects the conventions of democracy and constitutionalism, especially the separation of powers, the independence of the judiciary and the integrity of parliament. It may enter into a new and vibrant relationship with the electorate rather than the electorate being seen merely as voting fodder during occasional five-yearly general elections.

Pityana seems to be on to something here-although perhaps not quite in the way he imagines. What follows is an analysis of recent events located against debates on the nature of the party system in South Africa as dominated by the ANC, and international literature on democratic transition and especially consolidation. These views place great importance on elections as the main mechanism by which government is kept responsive. From this view stems the more parochial argument that although South Africa is formally a multiparty system, the electoral dominance of the ANC is such that it can take control of government for granted. This leads, it is held, to a dominant party 'syndrome' with various pathologies typical of one-party rule. This tendency, it is often suggested, has been exacerbated by the particular bureaucratic authoritarianism of Mbeki's rule. Our argument is that, assuming the dominant-party syndrome analysis is correct, the rise of Zuma counts against it both in Schumpeterian terms, but also on accounts of democracy that emphasise more greatly citizen participation in governance.

\section{Consolidating Liberal Democracy in South Africa}

Formally, South Africa is a liberal-democratic state under a constitution based on human rights, including civil and political rights to information, public debate and free political activity. The system of government is one in which power is spatially concentrated at the national level, although there are some provincial and local powers, and elections to all these bodies happen through a proportional-representation party list system (with the exception of half of local councillors who are elected from wards). Functionally, power is clearly separated between the judiciary on the one hand, and the executive and legislature on the other, but as in most parliamentary-type systems, the executive dominates the legislature. This is clearly exacerbated by ANC dominance, as will be discussed further below. Economically, the practice is similar to the 'third way' politics 
norm of pragmatic neo-liberal deregulation combined with a political commitment to meeting key social goods like health, education and welfare. In most ways then, the new South Africa is a fairly familiar liberaldemocratic capitalist system, something of an 'ironic victory' for liberalism given the anti-liberal ideologies of the NP and ANC prior to 1994 (Johnson and Welsh 1998).

In exploring the implications of recent political developments for the future of South African democracy, most political scientists refer to the extensive literature on democratic transition and consolidation of new democracies developed over the last twenty years. Theorising inductively from a comparative and empirical perspective, this literature follows Joseph Schumpeter in defining democracy as it is found in the real world: elite and/or party competition through elections, a procedural definition he argued was preferable to any other conception. Giovanni Sartori (1987: 152) too contends that democracy is the 'by-product of a competitive method of leadership recruitment'. On these conceptions of democracy, participation, apart from voting, is not taken to be a key indicator of democracy. In other words, popular input is 'at once all important yet minimal' (Parry and Moyser 1994: 46); important in that elections constitute the decisive point in democracy; minimal in that the ordinary citizen is asked to do little more than turn up at the polling station every few years.

While most mainstream political scientists would embrace a more developed and nuanced version of democracy than Schumpeter's, usually one following Robert Dahl's account of polyarchy or some version of associative democracy, there is no doubt that elections remain necessary and fundamental to all versions, if not sufficient. The search for indicators of democracy thus starts with competition between political leaders but does not end there because competition is not itself democracy: it produces democracy, democratic legitimacy and democratic accountability. That said, the core idea is that elections provide the most important form of elite accountability as voters will choose alternative leadership if they do not approve of the incumbents. Hence Thomas Pempel goes so far as to argue that a democracy which is not characterised by 'periodic examples of rascals actually flying through the doors' is not a convincing democracy at all (Pempel et al. 1990: 8).

Moving from this basic model, the consolidation literature examines the conditions under which democracy comes to be accepted as the legitimate way of deciding political power in a country that has undergone transition from authoritarian rule. Robert Mattes (2002) argues that there are three interconnected variables central to successful democratic consolidation: economic development, stable and predictable political institutions and a supportive political culture. Of the three of these, economic development is often taken to be the most important.

Consider for example, Seymour Martin Lipset's (1959) famous argument that there exists a clear correlation between economic well-being and democracy such that 'the more well-to-do a nation, the greater the chances that it will sustain democracy'. Adam Przeworski (2000) makes a related claim when he held that any country above an average per capita income of US $\$ 6000$ was extremely unlikely to backslide into authoritarianism. More recent arguments by Amartya Sen (1999) point to the relationship between democracy and reducing inequality, or at least meeting the basic needs of the poor. For Mattes (2002) the lesson suggested by all this literature is that the probabilities of democratic consolidation are dramatically enhanced when accompanied by economic development: that is economic growth and the reduction of inequality.

The reference to stable and predictable institutions centres firstly on the holding of free, fair and regular elections, and of course, abiding by the outcome of the elections. This latter point is of some significance, as illustrated by recent events in Kenya and Zimbabwe. Notably, the view is that stability and predictability extends beyond elections and would include the operation of government in terms of the constitution and/or the rule of law. Of key concern here would be the controlling foreign powers hostile to democracy and the marginalisation of the military from political power (Dahl 2008: 146), and then within civilian government the separation of powers, particularly the independence of the judiciary, so as to protect the rule of law. In many ways these constitute the basic minimum conditions of practice endorsed by the Washington consensus. However, most theorists would add further conditions associated with human rights, for example, Dahl's normative conditions of 'enlightened understanding of policy issues and debates' (2008: 37), aligned with rights to information and expression, and opportunities to input into the policy-making process, aligned to rights to participation beyond voting.

These latter points connect with the idea of the significance of political culture for democratic consolidation. Indeed in this respect it is notable that Dahl (1998: 158) refers to popular support for democracy as critical for its survival in times of crisis. This echoes an old idea, perhaps best expressed by Jean-Jacques Rousseau (1973: 228):

Along with these three kinds of law goes a fourth, most important of all, which is not graven on tablets of marble or brass, but on the hearts of the citizens. This forms the real constitution of the State, takes on every day new powers, when other laws decay or die out, restores them or takes their place, keeps a people in the ways in which it was meant to go, and insensibly replaces authority by the force of habit. I am speaking of morality, of custom, above all of public opinion; a power unknown to political thinkers, on which none the less success in everything else depends. With this the great legislator concerns himself in secret, though he seems to confine himself to particular regulations; for these are only the arc of the arch, while manners and morals, slower to arise, form in the end its immovable keystone. 
But in what would a supportive political culture consist? To this there is no one answer, but for mainstream liberal democrats it would be support for a democratic constitution and the rule of law, including key political freedoms such as speech, assembly, political pluralism and obviously the vote. Behind this would be notions of tolerance of political difference, and the resolution of political conflict through democratic institutions and law. For participatory democrats it would also involve notions of public entitlement to participation and voice in decision-making processes in all aspects of political life, and perhaps some notion of nonpartisan communitybuilding too.

It is less important to settle this question in any final way than to note that over the last ten years that the most trenchant criticism of South African democracy, most famously articulated by Herman Giliomee and Charles Simkins (1999), is the idea that ANC electoral dominance has led to political pathologies similar to those experienced in one-party states. These pathologies undermine democracy on any conception, but especially any hope for elite accountability through electoral competition. Indeed, many have suggested that the ANC's general tendency to take power for granted has been exacerbated under Mbeki's leadership given the centralisation of power in the Presidency during his tenure, and his reputation for intolerance of those opposed to his view. It is this analysis that frames the argument of our article.

\section{The Dominant Party System and Mbeki's 'Cantankerous Intransigence'2}

Giliomee and Simkins' work is heavily informed by the idea of 'Dominant Party Systems' as developed by Pempel in his 1990 book, Uncommon Democracies. Here Pempel explores one-party dominant regimes in advanced industrial democracies, arguing that the ruling parties in these states (Japan, Italy, Israel, Sweden) were responsive enough to citizens to stay in power and also successfully maintained democratic rights, freedom of the press, the presence of meaningful opposition parties and democratic culture. Hence, at least in developed contexts, it was possible for practices other than elections to keep political elites responsive.

In The Awkward Embrace Giliomee and Simkins examine dominant party regimes in new democracies in the developing world (Mexico, Taiwan, Malaysia, South Africa), asking whether one-party dominance is good for democracy. The answer, it seems, is mixed. Some theorists have pointed out that one-party dominance can facilitate (stability in a) democracy by entrenching the legitimacy of democratic institutions, by working to marginalise political extremes, fusing ethnic differences and creating consensus around compromise solutions to national problems (Pempel 1990; Reddy 2002). In other words, it is suggested that processes within a party may be more conducive to a democratic compromise than the competitive procedure of inter-party contestation.

Even more notable are the arguments offered by Julius Nyerere and to some extent Jomo Kenyatta, that democracy has in different situations been organised in specific historical forms, and the one-party system is one such form, as is the multi-party system. In some contexts, a dominant party can bring 'political stability and predictability in economic policy. If inclusive in recruitment, inclusive of a large section of the population, and pluralist in its functioning it can impact a great degree of legitimacy to a new regime' (Giliomee and Simkins 1999: xv). In other contexts though, they can blur the distinction between party and state, opening the door to large-scale corruption and the suppression of dissent. In such a context genuine competition falls by the wayside, the independence of the judiciary and civil service is undermined and responsiveness of government to citizens is replaced by an 20 attitude of entitlement to power.

In South Africa's case Giliomee and Simkins (1999: 347) argue that the latter scenario is closer to the truth. More specifically, they hold that the loyalty of the electorate to the ANC, the intolerance of the ANC of opponents and its belief in its exclusive legitimacy will lead to authoritarian and corrupt outcomes. To this argument, made some ten years ago, one could add a number of others that link the general problem of partydominance to the authoritarian characteristics of Mbeki's governance. For example, Tom Lodge (1999) points to a growing centralisation in ANC processes; Adam Habib and Roger Taylor (1999) discuss the growing dominance of the ANC in the tripartite alliance; Mattes (2002) refers to the rise of executive power at the expense of parliament; and Anthony Butler notes the concentration 30 of executive function in the office of the President. When added to perceptions about President Thabo Mbeki's 'zero-sum approach to power, viewing alternative sites of capacity as competitors rather than potential resources' (Butler 2000: 200), the overall trend towards the centralisation and concentration of political power is clear.

Indeed, there can be little doubt that the rise of factionalism in the ANC (although formally prohibited by the party constitution) was facilitated by the squeezing of democratic processes, and the ascension of Zuma over Mbeki has much to do with Mbeki's unpopularity. Hence Zuma enjoys support from a contradictory range of constituencies with no profound policy differentiation. For example, while the alliance partners support for Zuma does reflect an ideological disagreement with the '1996 neo-liberal project', it is Mbeki's exclusionary style which has largely marginalised the alliance which is the major spur to opposition. This point is reinforced by the lack of a clear and substantive alternative economic vision from the left beyond a frustration at the lack of delivery to the poor and working classes.

This example holds true for all differing elements in the party. It is precisely the closing down of consultation and debate, and the marginalisation and persecution of rivals like Zuma, which has generated the backlash against Mbeki. In many ways Mbeki's style of governance, and especially his denialism, created his own 
gravediggers. In this regard, it is worth asking whether, if Mbeki had not stood for President of the ANC at Polokwane, would Zuma still have won or would the party have rallied around a third- way candidate?

In sum, Mbeki has lost authority due to 'cantankerous intransigence'. At the same time his governance has also not lived up to the promise of the authoritarian response, which is greater effectiveness, especially in terms of delivery. Indeed, in the last few years effective delivery has taken second place to political loyalty (as shown by Mbeki's support for his Minister of Health), and eliminating rivals from power. Nevertheless, in our view he has done several things well, not least of which is to oversee the revival of economic growth and the expansion of the state welfare system, as well as champion a new era of positive African political development. Indeed, it is notable that from talking about 'two nations' in 1998, by 2008 Mbeki was talking about 'two economies'testimony to the rise of a new black middle and ruling class, the greatest winners under his rule, and the natural constituency of Mbeki's allies in COPE.

\section{Ironic Victory: Zuma, the Alliance and Factional Competition}

Given Giliomee and Simkins' arguments about the dominant-party syndrome and evidence of Zuma's own populist tendencies, can we really assume that the supplanting of Mbeki will solve the problem of arrogance at the heart of power? If Mbeki was able to take advantage of a lack of electoral competition to pursue his personal will over the will of the people, surely the same applies for Zuma? We advance two criticisms of this view: (i) as shown by the advent of Zuma, there are clearly sources of leadership competition other than opposition parties, and (ii) the assessment of dominance wrongly focuses on the ANC as party rather than the tripartite alliance as liberation movement.

The first claim is not as controversial as it may initially appear. Butler (2004: 120) points out that much contemporary international scholarship points to the role of non-electoral mechanisms in keeping political elites accountable. Indeed, this is a finding from Pempel's work on dominant party regimes in developed countries. Further, Butler (2004: 120-7) proceeds to list other sources of constraint on elite unilateralism in South Africa including state institutions like the human rights commission and other Chapter Nine institutions, but mostly the judiciary. Also important are the media, civil society organisations, the international audience and especially the international economy in terms of investors, and internal ANC party pluralism.

While the assessment of the significance of each of these factors is complex and too lengthy for the purposes of this article, we would hold that recent events clearly demonstrate the centrality of internal party pluralism as a constraint on elite power. It was the ANC, and more specifically the pro-Zuma faction in the ANC, that got rid of Mbeki. It was not parliament, nor civil society nor the media. Further, although it is a paradoxical claim, if one buys into the Schumpeterian view that democracy is about elite competition for popular support, then the factionalism in the ANC represents precisely this kind of competition, and hence following Schumpeter and his more sophisticated descendents, must be seen as good for democracy. Let us make this case in more detail.

A political faction is, by one common definition, 'a party within a party'. It is a group united by a common goal, the winning of power to advance the group agenda. Indeed historically the term faction was used as a synonym for political party, but with pejorative associations. One of the most famous characterisations of the faction is by American 'founding father' and President James Madison in his tenth instalment of the Federalist papers where he defines a faction as 'a number of citizens, whether amounting to a minority or majority of the whole, who are united and actuated by some common impulse of passion, or of interest, adverse to the rights of other citizens, or to the permanent and aggregate interests of the community'. He continues that of the 'numerous advantages promised by a well constructed Union, none deserves to be more accurately developed than its tendency to break and control the violence of faction'. More simply expressed a faction is a group that pursues self-interest at the expense of the common good.

Notably through, and this is the key point that drives the analogy, Madison's definition is very similar to the self-orientated conception of party politics advocated by Schumpeter and assumed in associational or pluralist conceptions of representative democracy. The point of the party is to win power, and to win power to advance the interests of the group it represents. Hence if party competition at elections is the mechanism by which elites are kept accountable, the same must apply for factional competition at elections. Is this not exactly what has happened with the election of Zuma? To put the point another way, through factionalism within the alliance we have the same kind of partisan competition that characterises multi-party elections. In addition, it is fair to say that most observers at the ANC conference that elected Zuma felt that the process was conducted in a democratic fashion, and that the most popular candidate won (see, for example, Friedman 2007). Hence, partisan competition produced a popular outcome. Further, taken as a whole, the tripartite alliance reasonably accurately reflects the major social groups in South African society, and certainly the major winners from Mbeki's governance (the middle classes in general, and the black middle classes in particular), and the (comparative) losers, working people and the poor, although there is some debate about the interests of COSATU/SACP and the poor. To put it in the terms of associational democrats, the alliance works to 'articulate interests' of the key social groups in the country-perhaps with the exception of relatively small racial minorities. In addition, there is reason to believe that the plural organisational character of the alliance creates the spaces for various members of the different interest groups represented by the tripartite alliance to contest party leadership into the future. Consider the various sub-structures of the ANC itself: the Youth League, 
Women's League, provinces, but especially the independently constituted and orientated unions and to a lesser extent, the SACP.

Lastly, as reflected in the Polokwane election, the major 'class projects' exist in rough equivalence of power. With the marginalisation of Mbeki's supporters in recent months and the secession of many to form COPE, it could be argued that the ANC has fragmented along broadly class lines, but it would be premature to ignore the significance of middle-class interests in the ANC into the future, not least as the socio-economic interests and lifestyle experience of those at the helm of the ANC and especially in government will inevitably tend to diverge with the grassroots members of COSATU and the SACP. Further, there are suggestions that the left is aware of the limits of their capacity to treat Zuma as a puppet. Assuming also that COPE and other opposition parties are able to capitalise on the divisive character of Zuma, it does look like a more left-leaning, working-class rooted ANC will confront a more popular centre-right, middle-class rooted, opposition into the future thus generating the particular combination of uncertainty and security required for leadership competition but not domination.

\section{Bringing the People Back In: The Alliance and Popular Mobilisation}

The above argument proceeds by embracing conventional associational or pluralist conceptions of democracy, and draws on the experience of democratic consolidation from elsewhere around the world. However, there are some problems with both this model of democracy and the theory of democratic consolidation. As John Gaventa (2006) points out, there is a paradox about contemporary democracy i $\mathrm{n}$ that at the very moment of the 'triumph' of liberal democracy as the hegemonic global polity, we have increasing talk of a 'democratic deficit' around the globe in both developed and developing contexts.

To our minds this phenomenon is rooted in the divergence that John Dunn identifies between the democracy as an ideal of political equality increasingly dispersed throughout the people around the world, and the reality of elite rule, especially elite economic rule with globalisation. As illustrated with dominant frequency, politics seems the exclusive preserve of politicians and their business sponsors, accessible to ordinary citizens only through legal recourse of rights talk and as represented by lawyers and other professional intermediaries.

Hence democracy becomes, in Dunn's (1979: 28) words, 'the name in politics for what we cannot have, yet cannot cease to want'. By this Dunn means that citizens cannot directly rule their own state. It is not that popular participation is totally excluded in these conceptions of democracy: it is that it exists in a diluted form, mediated through professionalised political leaders. But increasing numbers of scholars and activists disagree, at least in regard of some if not all forms of state power, and typically in respect of aspects of local governance. As illustrated by a growing number of successful cases from the developmental planning of villages in Kerala, to budgeting processes in Porto Alegre and town meetings in New England, citizen-centred forms of democracy are re-emerging.

In reclaiming the idea of democracy as being about participation and deliberation, participatory democrats are reclaiming the original and ancient meaning of democracy as about a community deliberating collectively on its problems, and implementing such decisions, under conditions of reasonable equality. These values are informed by alternative republican, participatory and deliberative models of democracy experienced around the world and in Africa too. For example the advocacy of participatory democracy under the slogan of 'people's power' in the UDF in South African in the 1980s; a legacy which has influenced the design of local governance in post-apartheid South Africa.

While there are different versions of citizen empowerment and the precise means by which it is to be achieved, the general institutional thrust is to look to supplement representative democracy with greater citizen participation and deliberation. A key factor in international empirical research on enhancing active citizenship centres on understanding why, how and by whom citizens are mobilised into action around collective goals (Gaventa et al. 2007). The point is that active citizenship is something that has to be claimed from political elites 'from below', usually by social movements demanding policy reform.

As Ballard et al. (2006) argue, there is a comparative dearth of social movements and a limited civil society in South Africa as the tripartite alliance historically played this role. It was the ANC and allies who mobilised people against apartheid, often around specific material grievances in the 1980 s for instance. But now that they are in power, there is something of an oppositional vacuum. Consequently, the members of the alliance are the key mobilising force around social issues, especially of poor people. Consider the popular mobilisation around the issues of HIV/AIDS, Zimbabwe and the basic income grant as examples.

Until substantial social movements appear the organisations most likely to get poor and marginalised people participating in politics remain the alliance partners. In this regard it is notable that Zuma is able to mobilise poor and marginalised constituencies much more effectively than social movements. Can we expect the alliance to mobilise people in a democratic fashion, especially given the reported tendency to resource competition within the ANC? It always remains possible for parties and unions to be captured by elites for their narrow ends, however, we think it reasonable to expect that, given its democratic traditions, COSATU remains mobilised around the general interests of its constituencies. 
In short, we have something of a triangulation effect-whether on associational competition or participatory mobilisation accounts-the alliance's reclaiming of the ANC is good for South Africa's democratic future.

\section{Disanalogies and Future Concerns}

Our argument that the rise of Zuma is good for South African democracy as internal party pluralism effected the popular elite alternation that formal elections could not have achieved should give the Schumpeterian reason for optimism into the future. However, to secure this confidence, there are two potential counterarguments that need to be addressed: the problem of disanalogy and the problem of economic growth.

First, and most important, is the claim that internal party factionalism as party competition has significant disanalogies which undermine the claim that the leadership competition between Zuma and Mbeki was indeed comparable to party electoral competition. Central here is the idea that the factions in the ANC did not operate on a public basis with clear platforms, nor did the delegations or the voting at the Polokwane conference reflect rank and file ANC views. Further, even if Polokwane was a democratic moment, it is far from clear that such democratic moments will be tolerated into the future.

While there is something to these views, none of them is fatal. As regards the transparency of factional politics, it seems common cause that the Mbeki-Zuma factionalism was public knowledge, and that those in the ANC were especially aware of these dynamics, including which team they were on. Indeed, it was probably the issue most widely deliberated among ANC activists and, for that matter, the chattering classes. Furthermore, the issue of policy difference between the factions matters little given the slight ideological differences between the factions.

As regards the durability of the democracy of the ANC's internal processes, the argument does rest heavily on this into the future as with the secession of key leadership from the ANC to COPE the prospects for both formal party competition and elite alternation through more formal democratic channels are enhanced. Simply put, intra-party factionalism did a job necessary at a particular time that formal elections could not do. This will probably not be the case into the future as opposition parties come to play a greater role in political life. Further, there is also evidence that younger voters display less blind party loyalty (Schultz- Herzenberg 2007).

The argument so far focuses on the dynamics around two of the three variables that matter in consolidation theory: stable and predictable political institutions, and supportive political culture. However, the third variable, enduring economic growth that reduces inequality, is still a co-requisite for greater pluralism to enhance responsiveness. It is cold comfort that the current recession has global rather than local roots. While it is beyond the scope of this article to interrogate closely this issue, we do note that the received opinion is that the economic health of South Africa is such that any recession ought to be comparatively limited, and that a return to positive growth should follow before too long. It is also worth noting that South Africa's average GDP hovers around a level where a reversion to authoritarianism would be unlikely, if not impossible. Given the lack of a substantively alternative macro-economic policy from the left, and a looming 2010 World Cup, there are some reasons for guarded optimism.

\section{Conclusion}

South African political life appears to be a dominant party system and hence vulnerable to authoritarian leadership, whether tyrannical Africanism or now patrimonial populism. However, the latter is now much less likely than often assumed, and largely thanks to the processes around the rise of Zuma as ANC President. The claim is not that Zuma is somehow the champion of the people in a way that Mbeki was not, but more that the factionalism in the ANC enabled its renaissance as 'liberation alliance', and that factionalism was ultimately a popularly driven process of elite alternation not possible through formal multi-party elections. In a sense then, Polokwane 2007 was a much more important election than the 2009 general election will be.

In many ways the factionalism in the ANC is understood as being about constituencies marginalised under Mbeki's rule struggling to access power, and the benefits that flow from that more broadly. At the organisational level the sea change in the ANC reflects the revival of influence of SACP/COSATU. At the societal level this is the equivalent of those members of the so-called 'second economy' demanding greater access to economic prosperity and political recognition. Notably this has yet to translate into clear shifts in policy, but it is reasonable to expect that COSATU and the SACP will increase the pressure to move governance in a proworker and pro-poor direction after the 2009 elections.

Further, the sea change in the ANC is good for democracy understood in at least two ways. First, and somewhat ironically, the ANC as revived alliance recaptures the appropriate balance between competition and stability required for 'democratic consolidation' as defined in the mainstream political science approach to democracy as electoral competition for power under the rule of law. Indeed, not only did ANC factionalism allow for elite alternation that could not have happened through formal elections, but did so without threatening fundamentally the ANC, and possibly, the democratic system as a whole. Further the emergence of COPE and prospects of heightened party pluralism into the future take the competitive burden off the ANC's internal democratic processes into the future.

Second, a revived alliance is good for democracy understood in terms of the better inclusion of poor and marginalised groups in a liberal-representative system experiencing significant democratic deficit. In the 
absence of a range of vibrant social movements, COSATU and the SACP have been the organisations mobilising communities, and especially the poor on social issues. In some ways this insight is potentially more important as democracy as electoral competition cannot guarantee clean or wise rule, just less exclusive rule. Participatory processes however, promise a little more.

\section{NOTES}

1. Our thanks to David Spurrett for this point.

2. Richard Calland. 2008. The dark side of the second transition, Mail \& Guardian Online, 19 February, available at http://mg.co.za/article/2008-02-18-the-dark-side-of-the-second-transition 


\section{REFERENCES}

BALLARD, RICHARD, ADAM HABIB and IMRAAN VALODIA (eds.) 2006. Voices of Protest: Social Movements in Post-Apartheid South Africa. Pietermaritzburg: UKZN Press.

BUTLER, ANTHONY. 2000. Is South Africa heading towards authoritarian rule? Instability myths and expectations traps in a new democracy. Politikon 27(2): 189-206.

BUTLER, ANTHONY. Contemporary South Africa. Basingstoke: Palgrave.

DAHL, ROBERT. 1998. On Democracy. New Haven and London: Yale University Press.

FRIEDMAN, STEVEN. 2007. No dear, that's not mob rule it's called democracy, Weekly Mail \& Guardian, available at http://www.thoughtleader.co.za/stevenfriedman/2007/12/17/no-dear-thatsnot-mob-rule-itscalled-democracy/ (accessed 11 March 2009).

GAVENTA, JOHN. 2006. Triumph, deficit or contestation: deepening the deepening democracy debate, IDS Working Paper 264.

GAVENTA, JOHN, ROSEMARY MCGEE and TRICIA ZIPFEL. 2007. How do local governments support citizen engagement? Background note for the International Workshop for Champions of Participation in Local Government, Institute of Development Studies, University of Sussex, Brighton, 29 May-4 June.

GILIOMEE, HERMAN and CHARLES SIMKINS (eds.). 1999. The Awkward Embrace: One-Party Dominance and Democracy. Cape Town: Tafelberg.

HABIB, ADAM and RUPERT TAYLOR. 1999. Daring to question the tripartite alliance: A response to Southall and Wood. Transformation 40: 112-20.

JOHNSON, ROBERT W. and DAVID WELSH (eds.). 1998. Ironic victory: Liberalism in Post-Liberation South Africa. Cape Town: Oxford.

LIPSET, SEYMOUR MARTIN. 1959. Some social requisites of democracy: Economic development and political legitimacy. The American Political Science Review 53 (1): 69-105.

LODGE, TOM. 1999. Policy processes within the African National Congress and the Tripartite Alliance. Politikon 26 (1): 5-32.

MADISON, JAMES. The Federalist Papers, available online at http://federali.st/ (accessed 5 January 2009). MATTES, ROBERT. 2002. Democracy without the people: Economics, governance, and representation in South Africa. Journal of Democracy 13 (1): 22-36.

PEMPEL, THOMAS (ed.). 1990. Uncommon Democracies: The One-Party Dominant Regimes. Ithaca, NY: Cornell University Press.

PITYANA, BARNEY. 2008. The future of our nation-our nation of the future: On morality in politics, the law and society. Address at the Annual General Meeting of the Law Society of South Africa, Stellenbosch, 31 March 2008, available online at

http://www.unisa.ac.za/contents/about/principle/docs/THE\%2OFUTURE\%20OF\%20OUR\%20NATION\%20

Address\%20to\%20Law\%20Society\%202008.pdf (accessed April 2008)

PRZEWORSKI, ADAM, MICHAEL E. ALVAREZ, JOSE ANTONIO CHEIBUB and FEWRNANDO LIMONGI (eds.). 2000.

Democracy and Development: Political Institutions and Well-being in the World, 1950-199o. Cambridge: Cambridge University Press.

SCHULZ-HERZENBERG, COLLETE. 2007. A Silent Revolution: South African Voters, 1994-1996. In Sanele Buhlungu, John Daniel, Roger Southall and Jessica Lutchman (eds.), State of the Nation. Pretoria: HSRC Press, pp. xx-yy.

SEN, AMARTYA. 1999. Development as Freedom. Oxford: Oxford University Press.

Laurence Piper is Professor and Head of the Department of Political Studies at the University of the Western Cape. With a PhD from Cambridge in 2000, he has published extensively on Zulu nationalism, the Inkatha Freedom Party and electoral politics in South Africa. His current research interests sit at the intersection of new democratic innovations, local governance and development in the global south. E-mail:

laurencepiper@gmail.com

Heidi Matisonn is currently in the finishing stages of her PhD in the London School of Economics (LSE) Government Department. She has been back in South Africa for the last four years where she is a lecturer in political philosophy at the University of KwaZulu-Natal. Her dissertation, entitled 'Making Democracy Work Better: Civic Traditions in South Africa and Brazil' started out as empirical political theory but has shifted to something much more normative with much of the theory underpinning the research being political and moral philosophy.

E-mail: matisonnh@ukzn.ac.za 
